\title{
Praktikalitas dan Efektivitas Modul Geometri Transformasi Berbantuan Geogebra bagi Mahasiswa Pendidikan Matematika
}

\author{
Ratri Isharyadi ${ }^{\text {, Marfi Ario }}{ }^{2}$ \\ Universitas Pasir Pengaraian \\ 2Universitas Pasir Pengaraian \\ aryamath@ymail.com \\ marfi.ario.92@gmail.com
}

\begin{abstract}
ABSTRAK Geometri transformasi merupakan salah satu matakuliah wajib bagi program studi Pendidikan matematika. Salah satu permasalahan yang ditemui pada pembelajaran geometri transformasi adalah sumber belajar yang masih sedikit. Buku ajar yang ada adalah buku ajar yang telah lama terbit, sehingga salinannya kurang terlihat. Modul yang dihasilkan dari penelitian ini adalah modul geometri transformasi berbantuan GeoGebra. Dengan memadukan pengetahuan geometri dengan teknologi, sehingga menghasilkan tranformasi geometri dengan preview yang presisi. Hasil penelitian ini adalah modul geometri transformasi yang praktis dan efektif. Hasil uji kepraktisan menunjukkan nilai 83,8 dan termasuk kedalam kategori sangat baik. Sedangkan hasil uji efektivitas, menunjukkan bahwa rerata yang diperoleh adalah 72,5 dan termasuk kedalam kategori baik. Hasil ini diketahui berdasarkan analisis terhadap lembar angket dan lembar soal geometri transformasi sebagai instrumen praktikalitas dan efektivitas modul.
\end{abstract}

Kata-kata Kunci: efektivitas, GeoGebra, geometri transformasi, praktikalitas.

\section{PENDAHULUAN}

Teknologi telah berkembang dengan pesat, banyak permasalahan dalam kehidupan yang dapat diselesaikan dengan teknologi. Pendidikan saat ini hendaknya sudah terintegrasi dengan teknologi. Hal ini dapat dilakukan dengan memanfaatkan program komputer/ software yang ada di internet. Teknologi telah menjadi salah satu sumber belajar yang kuat. Evolusi dalam menggunakan teknologi dalam pengajaran dan proses pembelajaran telah berkembang pesat (Arbain \& Shukor, 2015). Salah satu penggunaan teknologi dalam pembelajaran adalah menggunakan aplikasi dalam geometri. Terdapat beberapa program komputer yang dapat digunakan dalam geometri, diantaranya yaitu Geometers Sketchpad, Cabri, dan GeoGebra.

Tujuan pembelajaran geometri adalah agar mahasiswa mempunyai rasa percaya diri mengenai kompetensi matematis, diantaranya pemecahan masalah, berkomunikasi, bernalar secara matematis, mengembangkan kemampuan berpikir logis, dan mengembangkan intuisi. Geometri transformasi merupakan salah satu 
matakuliah wajib bagi program studi Pendidikan matematika. Dengan diajarkannya geometri mulai dari tingkat dasar, seharusnya hal ini memudahkan mahasiswa dalam memahami geometri transfromasi. Salah satu kesulitan dari pembelajaran geometri adalah dalam menampilkan geometri secara presisi. Dalam penggambaran secara manual, memungkinkan terjadinya ketidakakuratan gambar yang dibuat. Masalah lain yang ditemui di Program Studi Pendidikan Matematika Universitas Pasir Pengaraian adalah minimnya sumber belajar/ buku yang ada. Sumber belajar yang ada adalah buku yang telah lama terbit, dan sulit menemukan edisi terbarunya. Buku tersebut adalah salinan yang di dalamnya terdapat beberapa bagian yang penyajiannya kurang jelas. Selain itu, mahasiswa masih mengandalkan sumber belajar yang disediakan oleh pengajarnya, dan kurang memiliki inisiatif dalam mencari sumber belajar lain.

Menurut Idris (Seloraji, 2017), kurangnya pemahaman dalam pembelajaran geometri sering menyebabkan keputusasaan di antara siswa, yang akan menyebabkan kinerja geometri yang buruk. Dia mengklaim bahwa beberapa faktor telah diidentifikasi menyebabkan kesulitan dalam pembelajaran geometri; ini adalah bahasa geometri, kemampuan visualisasi dan instruksi yang tidak efektif. Dari hasil analisis terhadap kebutuhan bahan ajar bagi mahasiswa, 69,6\% mahasiswa menganggap dalam pembelajaran geometri transformasi membutuhkan buku ajar, dan $78 \%$ menganggap buku ajar tersebut hendaknya terintegrasi dengan teknologi. Teknologi dianggap oleh $87 \%$ mahasiswa sangat diperlukan dalam mempermudah visualisasi gambar geometri. (Isharyadi \& Ario, 2018a). Berdasarkan hal tersebut, bahan ajar yang dikembangkan harus terintegrasi dengan teknologi.

Menurut Depdiknas (2008) bahan ajar adalah segala bentuk bahan yang digunakan untuk membantu guru/ instruktur dalam melaksanakan kegiatan belajar mengajar. Bahan yang dimaksud bisa berupa bahan tertulis maupun bahan tidak tertulis. Lebih lanjut disebutkan bahwa bahan ajar berfungsi sebagai:

1. Pedoman bagi Guru yang akan mengarahkan semua aktivitasnya dalam proses pembelajaran, sekaligus merupakan substansi kompetensi yang seharusnya diajarkan kepada siswa.

2. Pedoman bagi siswa yang akan mengarahkan semua aktivitasnya dalam proses pembelajaran, sekaligus merupakan substansi kompetensi yang seharusnya dipelajari/dikuasainya.

3. Alat evaluasi pencapaian/penguasaan hasil pembelajaran.

Salah satu bahan ajar tertulis yang telah banyak dikembangkan adalah modul. Menurut Daryanto (2013) modul merupakan alat atau sarana yang berisi materi, metode, batasan-batasan, dan cara mengevaluasi yang dirancang secara sistematis dan menarik untuk mencapai kompetensi yang diharapkan. Modul yang dikembangkan adalah modul yang terintegrasi dengan teknologi, yaitu software GeoGebra. Preiner (Praveen \& Leong, 2013) menyatakan bahwa pengintegrasian teknologi ke dalam pembelajaran matematika terbagi kedalam dua bentuk. Pertama, ada manipulatif virtual yang terdiri dari lingkungan belajar interaktif tertentu. Dalam pengaturan manipulatif virtual, siswa dapat mengeksplorasi konsep-konsep matematika tanpa keterampilan komputer khusus atau pengetahuan tentang paket 
perangkat lunak. Kedua, ada perangkat lunak matematika yang sesuai untuk tujuan pendidikan dan dapat digunakan untuk berbagai macam topik konten matematika, sehingga memungkinkan lebih banyak fleksibilitas dan memungkinkan guru dan siswa untuk mengeksplorasi konsep-konsep matematika.

GeoGebra adalah software gratis yang dikembangkan oleh Markus Hohenwater. Software ini dapat diakses melalui aplikasi komputer ataupun melalui web. Software ini memiliki 2 tampilan, yaitu tampilan aljabar dan tampilan geometri. Pengguna dapat melihat tampilan secara geometris dari sebuah bentuk aljabar. Gambar hasil translasi aljabar ke geometris akan tampil dengan sangat presisi, dan dapat diperbesar, sehingga memungkinkan untuk melihatnya secara detail. Hohenwater (Joglar Prieto, Sordo Juanena, \& Star, 2014) menyatakan bahwa GeoGebra dapat digunakan dalam banyak cara dalam pengajaran dan pembelajaran matematika, yaitu:

a. untuk demonstrasi dan visualisasi, karena dapat memberikan representasi yang berbeda,

b. sebagai alat konstruksi, karena memiliki kemampuan untuk membangun bentuk,

c. untuk penyelidikan untuk menemukan matematika, karena dapat membantu menciptakan suasana yang cocok untuk belajar.

Hasil penelitian oleh (Arbain \& Shukor, 2015) menunjukkan bahwa perangkat lunak GeoGebra memiliki dampak positif pada prestasi siswa. Para siswa juga memiliki persepsi positif pada perangkat lunak GeoGebra dalam hal antusiasme, kepercayaan diri, dan motivasi. Hasil penelitian (Alkhateeb \& Al-Duwairi, 2019) juga menunjukkan bahwa rerata hasil belajar siswa yang menggunakan GeoGebra lebih tinggi dilihat dari pengetahuan konsep, proses dan pemecahan masalah dibandingkan dengan siswa yang belajar menggunakan geometers sketchpad dan cara konvensional. Perangkat lunak ini harus diperkenalkan kepada pendidik matematika sehingga siswa dapat menjelajahi dunia matematika secara lebih luas dan membuat siswa mampu berpikir kritis dan kreatif.

Modul ajar geometri transformasi yang dikembangkan merupakan modul yang valid. Hal ini berdasarkan hasil pengujian kevalidan modul dari ketiga validator dengan rincian rata-rata skor total ahli materi dan ahli media masing-masingnya yaitu 3,38 dan 3,21 dengan kriteria keduanya yaitu sangat baik (Isharyadi \& Ario, 2018b). Penelitian ini dilakukan untuk melihat apakah modul yang valid tersebut merupakan modul yang praktis dan efektif.

\section{METODE PENELITIAN}

Model pengembangan yang digunakan dalam penelitian ini merujuk pada teori model pengembangan 4D yang merupakan kepanjangan dari define, design, development, and dissemination. Pada penelitian ini merupakan kelanjutan dari tahap validasi modul yang telah dilakukan dan menghasilkan modul yang valid. Fokus penelitian ini adalah untuk melihat kepraktisan dan keefektifan modul yang dibuat. 
a. Praktikalitas

Praktikalitas merupakan tingkat keterpakaian modul geometri transformasi oleh mahasiswa, dengan melakukan uji coba menggunakan modul yang telah direvisi. Uji coba dilakukan pada kelas yang telah mempelajari mata kuliah geometri transformasi. Modul dikatakan praktis jika pengguna tidak kesulitan memahami materi yang disajikan, mudah pemeriksaannya serta lengkap dengan petunjuk yang jelas. Jika hasil belum praktis, dilakukan perbaikan dan hasil perbaikan harus divalidasi terlebih dahulu. Setelah hasil perbaikan dinyatakan valid, dilakukan uji praktikalitas terhadap perbaikan. Ini dilakukan sampai ditemukan modul yang praktis. Analisis uji kepraktisan modul dilakukan dengan memberikan kuisioner bagi mahasiswa, dengan penentuan persentase per item berdasarkan kriteria berikut.

$$
p=\frac{\sum \text { skor peritem }}{\text { skor mak } \times n \text { validator peritem }} \times 100 \%
$$

\section{Tabel 1. Kategori Hasil Penilaian dalam Persentase}

\begin{tabular}{cc}
\hline Interval (\%) & Kategori \\
\hline $0-20$ & Tidak Baik \\
\hline $21-40$ & Kurang Baik \\
\hline $41-60$ & Cukup \\
\hline $61-80$ & Baik \\
\hline $81-100$ & Sangat Baik
\end{tabular}

Modul dikatakan praktis bila berada pada kriteria baik dan sangat baik.

b. Tahap Efektivitas

Tahap ini dilakukan setelah modul dinyatakan praktis. Kegiatan dipusatkan untuk mengevaluasi apakah modul geometri transformasi dapat digunakan untuk mencapai tujuan yang efektif dalam meningkatkan kualitas dan prestasi belajar mahasiswa. Analisis efektivitas dilakukan dengan menghitung rata-rata nilai mahasiswa setelah mengikuti tes yang kemudian dikonversi kedalam rentang 0 - 100 dengan rumus berikut:

$$
\text { rata }- \text { rata nilai }=\frac{\text { jumlah nilai seluruh mahasiswa }}{\text { banyak mahasiswa }} \times 100
$$

Interpretasi rata-rata nilai yang diperoleh mengacu pada sistem penilaian di Universitas Pasir Pengaraian, yaitu sebagai berikut:

Tabel 2. Interpretasi nilai

\begin{tabular}{ccc}
\hline Interval & Nilai & Kriteria \\
\hline $85 \leq$ Nilai $\leq 100$ & A & Sangat Baik \\
\hline $65 \leq$ Nilai $<85$ & B & Baik \\
\hline $55 \leq$ Nilai $<65$ & C & Cukup \\
\hline $45 \leq$ Nilai $<65$ & D & Kurang \\
\hline $0 \leq$ Nilai $<45$ & E & Gagal \\
\hline
\end{tabular}


Modul geometri transformasi dikatakan efektif bila berada pada kategori baik dan sangat baik.

\section{HASIL DAN PEMBAHASAN}

Modul geometri transformasi yang dihasilkan memuat tiga materi utama, yaitu refleksi, setengah putaran dan translasi. Setiap bab memiliki pembahasan berupa pembuktian teorema dan langkah-langkah penyelesaian masalah menggunakan GeoGebra. Pada bagian akhir setiap bab diberikan latihan yang juga memuat praktik penggunaan GeoGebra. Penerapan modul dilakukan pada mahasiswa semester $V$ program studi Pendidikan Matematika Universitas Pasir Pengaraian yang berjumlah 26 orang. Penerapan pembelajaran menggunakan modul dimulai dengan penjelasan oleh peneliti kepada mahasiswa, selanjutnya berdasarkan latihan yang terdapat pada modul, mahasiswa melakukan aktivitas menyelesaikan soal-soal latihan dengan cara manual. Mahasiswa diminta untuk membawa perangkat pendukung pembelajaran, yaitu laptop yang telah terinstal di dalamnya aplikasi GeoGebra. Selanjutnya, mahasiswa diberi penjelasan menyelesaikan masalah yang sama menggunakan teknologi, yaitu aplikasi GeoGebra.

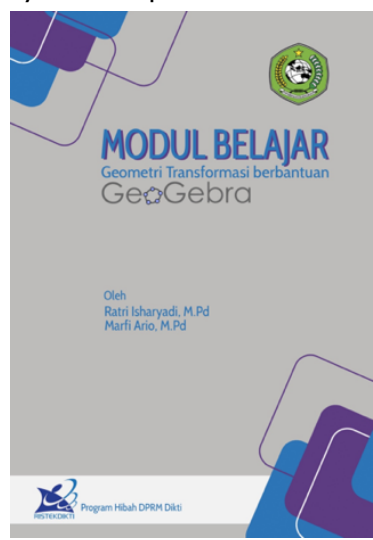

Gambar 1. Cover modul belajar geometri transformasi

Langkah-langkah penyelesaian menggunakan GeoGebra tertulis pada modul, sehingga mahasiswa dapat dengan mudah mempelajarinya.

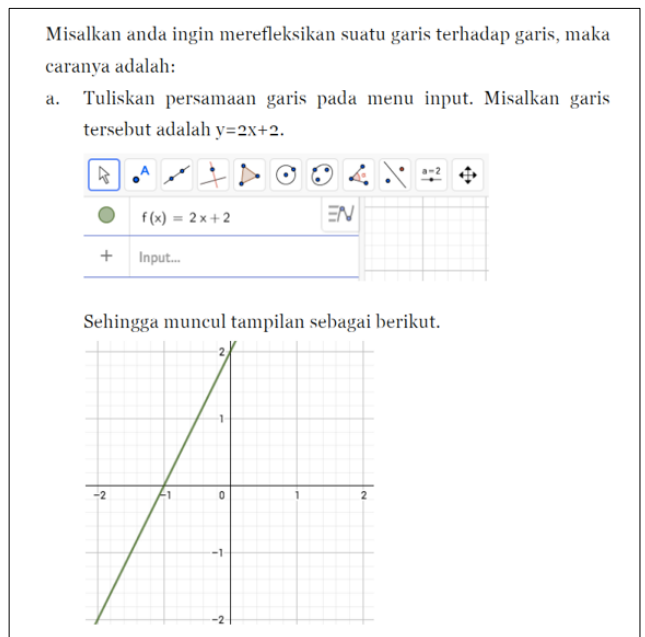

Gambar 2. Langkah-langkah menggunakan GeoGebra 
Pada akhir pertemuan, mahasiswa diminta untuk mengisi kuisioner berkaitan dengan kepraktisan modul. Kuisioner ini terdiri atas sebelas item pernyataan, dengan skor setiap pernyataan dari 1 sampai dengan 5. Hasil kuisioner dapat dilihat pada tabel berikut.

Tabel 3. Hasil kuisioner kepraktisan modul

\begin{tabular}{clcc}
\hline No & \multicolumn{1}{c}{ Aspek Penilaian } & $\begin{array}{c}\text { Rerata } \\
\text { Nilai }\end{array}$ & $\begin{array}{c}\text { Rerata } \\
\text { dalam \% }\end{array}$ \\
\hline 1 & Bahan ajar mudah untuk dibawa dan dibaca & 4,27 & 85,4 \\
\hline 2 & Tulisan pada bahan ajar terlihat dengan jelas & 4,16 & 83,2 \\
\hline 3 & $\begin{array}{l}\text { Gambar pada bahan ajar terlihat dengan } \\
\text { jelas }\end{array}$ & 3,94 & 78,8 \\
\hline 4 & $\begin{array}{l}\text { Bahasa yang digunakan pada bahan ajar } \\
\text { mudah dimengerti }\end{array}$ & 3,72 & 74,4 \\
\hline 5 & $\begin{array}{l}\text { Materi yang disampaikan pada bahan ajar } \\
\text { mudah dipahami }\end{array}$ & 3,78 & 75,6 \\
\hline 6 & $\begin{array}{l}\text { Materi pada bahan ajar dijelaskan secara } \\
\text { sistematis }\end{array}$ & 4,05 & 81 \\
\hline 7 & $\begin{array}{l}\text { Materi yang disajikan pada bahan ajar sesuai } \\
\text { dengan materi perkuliahan }\end{array}$ & 4,44 & 88,8 \\
\hline 8 & Bahan ajar membantu dalam proses belajar & 4,61 & 92,2 \\
\hline 9 & Bahan ajar bisa menjadi sumber belajar & 4,61 & 92,2 \\
\hline 10 & $\begin{array}{l}\text { Bahan ajar membantu dalam memahami } \\
\text { materi }\end{array}$ & 4,33 & 86,6 \\
\hline 11 & $\begin{array}{l}\text { Bahan ajar yang ada memberi kemudahan } \\
\text { dalam belajar }\end{array}$ & 4,22 & 84,4 \\
\hline & Rerata total & 4,19 & 83,8 \\
\hline
\end{tabular}

Berdasarkan kriteria yang digunakan untuk menentukan kepraktisan modul, rerata total adalah $83,8 \%$, hal ini menunjukkan bahwa kepraktisan modul berada pada kategori sangat baik. Bila dilihat per masing-masing item, pernyataan bahasa yang digunakan pada bahan ajar mudah dimengerti memperoleh skor terendah, yaitu $74,4 \%$, namun skor tersebut masih termasuk dalam kategori baik. Dalam geometri transformasi, banyak simbol-simbol yang digunakan, sehingga memiliki kemungkinan menjadi penyebab rendahnya skor pada item tersebut. Pernyataan bahan ajar membantu dalam proses belajar dan bahan ajar bisa digunakan sebagai sumber belajar memperoleh skor tertinggi, dengan $92,2 \%$. Hal ini menunjukkan bahwa mahasiswa dapat menggunakan modul geometri transformasi berbantuan GeoGebra sebagai sumber belajar dan dapat membantu dalam proses belajar.

Pada kuisioner kepraktisan modul, peneliti juga memberikan kolom komentar kelebihan, kekurangan dan saran. Hal ini dilakukan agar mahasiswa dapat menuliskan segala sesuatu yang dirasa penting berkaitan dengan kepraktisan, namun tidak terfasilitasi melalui item pernyataan yang tersedia. Umumnya, mahasiswa memberikan komentar yang positif terhadap modul ajar dan 
menyatakan bahwa modul ajar memberikan kemudahan bagi mereka dalam belajar geometri transformasi.

Selain memberikan kuisioner tentang kerpaktisan modul, peneliti juga memberikan tes kepada mahasiswa setelah memperoleh pembelajaran menggunakan modul. Hal ini dilakukan untuk melihat hasil belajar mahasiswa berkaitan dengan efektivitas modul yang dikembangkan. Tes yang diberikan berbentuk uraian, yang terdiri atas 5 soal. Hasil tes tersebut dapat dilihat pada table berikut.

\section{Tabel 4. Deskripsi data tes hasil belajar}

\begin{tabular}{cc}
\hline Deskripsi data & Nilai \\
\hline Rerata & 72,5 \\
\hline Simpangan baku & 17,94 \\
\hline Skor maksimum & 100 \\
\hline Skor minimum & 35 \\
\hline Skor maksimum ideal & 100 \\
\hline Skor minimum ideal & 0 \\
\hline
\end{tabular}

Tabel 5. Persebaran nilai mahasiswa

\begin{tabular}{cccc}
\hline Interval nilai & Nilai & Frekuensi & Persentase \\
\hline $85 \leq$ Nilai $\leq 100$ & A & 14 & $53,85 \%$ \\
\hline $65 \leq$ Nilai $<85$ & B & 5 & $19,23 \%$ \\
\hline $55 \leq$ Nilai $<65$ & C & 3 & $11,54 \%$ \\
\hline $45 \leq$ Nilai $<65$ & D & 0 & 0 \\
\hline $0 \leq$ Nilai $<45$ & E & 4 & $15,28 \%$ \\
\hline Total & & 26 & $100 \%$ \\
\hline
\end{tabular}

Berdasarkan hasil tes yang diberikan, terlihat bahwa rerata yang diperoleh adalah 72,5. Nilai rerata tersebut termasuk dalam kategori baik. Berdasarkan kriteria yang telah ditetapkan, modul ajar dikatakan efektif bila termasuk ke dalam kategori baik dan sangat baik (nilai berada pada interval A dan B), maka modul ajar geometri transformasi berbantuan GeoGebra merupakan modul yang efektif. Bila dilihat dari persentase persebaran nilai, diperoleh bahwa 73,08 \% mahasiswa memperoleh nilai A dan $B$ dan sisanya $26,92 \%$ memperoleh nilai $C$ dan $E$. Hasil ini menunjukkan bahwa modul efektif digunakan dalam pembelajaran.

Perangkat lunak GeoGebra memberikan kemudahan bagi mahasiswa dalam menyelesaikan permasalahan geometri transformasi, khususnya pada materi refleksi, setengah putaran dan geseran/ translasi. Dengan langkah-langkah yang diberikan pada modul, cara yang serupa dapat diterapkan pada permasalahan yang lain. Mahasiswa dapat mengeksplore secara mandiri semua menu-menu yang terdapat pada GeoGebra. Tampilan yang dihasilkan pada bagian grafis geometri juga sangat akurat. Mahasiswa dapat mengganti persamaan aljabar pada bagian aljabar dan grafiknya akan berubah secara dinamis pada bagian grafis. 


\section{KESIMPULAN DAN SARAN}

Modul geometri tansformasi berbantuan GeoGebra merupakan modul yang praktis dan efektif untuk digunakan dalam pembelajaran. Hasil uji kepraktisan menunjukkan nilai 83,8 dan termasuk kedalam kategori sangat baik. Sedangkan hasil uji efektifitas, menunjukkan bahwa rerata yang diperoleh adalah 72,5 dan termasuk kedalam kategori baik. Beberapa bagian dari materi geometri transformasi tidak memungkinkan menggunakan GeoGebra, namun masih terdapat beberapa materi yang bias memanfaatkan GeoGebra dalam pembelajarannya, yaitu rotasi dan dilatasi. Peneliti selanjutnya dapat mengembangkan modul dengan materi tersebut.

\section{UCAPAN TERIMAKASIH}

Ucapan terimakasih untuk DRPM Dikti atas bantuan dana pada penelitian ini dalam skema penelitian dosen pemula dan kepada pihak-pihak terkait yang telah membantu telaksananya penelitian ini.

\section{DAFTAR PUSTAKA}

Alkhateeb, M. A., \& Al-Duwairi, A. M. (2019). The Effect of Using Mobile Applications (GeoGebra and Sketchpad) on the Students' Achievement. International Electronic Journal of Mathematics Education, 14(3), 523-533. https://doi.org/10.29333/iejme/5754

Arbain, N., \& Shukor, N. A. (2015). The Effects of GeoGebra on Students Achievement. Procedia - Social and Behavioral Sciences, 172(2007), 208-214. https://doi.org/10.1016/j.sbspro.2015.01.356

Nasional, D. P. (2008). Panduan pengembangan bahan ajar.

Daryanto, S., \& Mengajar, T. (2013). Bandung, CV. Prama Widya.

Isharyadi, R., \& Ario, M. (2018a). Analisis Kebutuhan Modul Ajar Geometri Transformasi berbantuan GeoGebra untuk Mahasiswa Pendidikan Matematika. Prosiding Seminar Nasional Teknopreneur 1, 1 (1), 579-584.

Isharyadi, R., \& Ario, M. (2018b). Pengembangan modul berbantuan GeoGebra pada perkuliahan geometri transformasi. Guru Tua, 1 (1), 1-8.

Joglar Prieto, N., Sordo Juanena, J. M., \& Star, J. R. (2014). Designing Geometry 2.0 learning environments: a preliminary study with primary school students. International Journal of Mathematical Education in Science and Technology, 45(3), 396-416. https://doi.org/10.1080/0020739X.2013.837526

Praveen, S., \& Leong, K. E. (2013). Effectiveness of Using GeoGebra on Students ' Understanding in Learning Circles. The Malaysian Online Journal of Educational Technology, 1(4), 1-11.

Seloraji, P. dan L. K. E. (2017). Students' Performance in Geometrical Reflection Using GeoGebra. Malaysian Online Journal of Educational Technology, 5(1), 65-77. 